The University of San Francisco

USF Scholarship: a digital repository @ Gleeson Library |

Geschke Center

\title{
Use of Flow Cytometry and Stable Isotope Analysis to Determine Phytoplankton Uptake of Wastewater Derived Ammonium in a Nutrient-rich River
}

\author{
Calla Schmidt
}

University of San Francisco, cischmidt@usfca.edu

Tamara E. C. Kraus

Megan B. Young

Carol Kendall

Follow this and additional works at: https://repository.usfca.edu/envs

\section{Recommended Citation}

Schmidt, Calla; Kraus, Tamara E. C.; Young, Megan B.; and Kendall, Carol, "Use of Flow Cytometry and Stable Isotope Analysis to Determine Phytoplankton Uptake of Wastewater Derived Ammonium in a Nutrient-rich River" (2017). Environmental Science. 38.

https://repository.usfca.edu/envs/38 


\title{
Use of flow cytometry and stable isotope analysis to determine phytoplankton uptake of wastewater derived ammonium in a nutrient-rich river
}

\author{
Calla M. Schmidt ${ }^{1}$, Tamara E. C. Kraus ${ }^{2}$, Megan B. Young ${ }^{3}$, Carol Kendall ${ }^{3}$ \\ ${ }^{1}$ University of San Francisco, 2130 Fulton St, San Francisco, CA, 94117, USA \\ ${ }^{2}$ USGS California Water Science Center, 6000 J Street, Placer Hall, Sacramento CA 95819, USA \\ ${ }^{3}$ USGS National Research Program, Menlo Park, CA, USA \\ Correspondence to: Calla M Schmidt (cischmidt@usfca.edu)
}

\begin{abstract}
Anthropogenic alteration of the form and concentration of nitrogen $(\mathrm{N})$ in aquatic ecosystems is widespread. Understanding availability and uptake of different $\mathrm{N}$ sources at the base of aquatic food webs is critical to establishment of effective nutrient management programs. Stable isotopes of $\mathrm{N}\left({ }^{14} \mathrm{~N},{ }^{15} \mathrm{~N}\right)$ are often used to trace the sources of $\mathrm{N}$ fuelling aquatic primary production, but effective use of this approach requires obtaining a reliable isotopic ratio for phytoplankton. In this study, we tested the use of flow cytometry to isolate phytoplankton from bulk particulate organic matter (POM) in a portion of the Sacramento River, California, during river-scale nutrient manipulation experiments that involved halting wastewater discharges high in ammonium $\left(\mathrm{NH}_{4}{ }^{+}\right)$. Field samples were collected using a Lagrangian approach, allowing us to measure changes in phytoplankton $\mathrm{N}$ source in the presence and absence of wastewater derived $\mathrm{NH}_{4}{ }^{+}$. Comparison of $\delta^{15} \mathrm{~N}-\mathrm{POM}$ and $\delta^{15} \mathrm{~N}$-phytoplankton $\left(\delta^{15} \mathrm{~N}-\mathrm{PHY}\right)$ revealed that their $\delta^{15} \mathrm{~N}$ values followed broadly similar trends. However, after 3 days of downstream travel in the presence of wastewater treatment plant (WWTP) effluent, $\delta^{15} \mathrm{~N}-\mathrm{POM}$ and $\delta^{15} \mathrm{~N}-\mathrm{PHY}$ in the Sacramento River differed by as much as $7 \%$. Using a stable isotope mixing model approach, we estimated that in the presence of effluent between 40 and $90 \%$ of phytoplankton- $\mathrm{N}$ was derived from $\mathrm{NH}_{4}{ }^{+}$after 3 days of downstream transport. An apparent gradual increase over time in the proportion of $\mathrm{NH}_{4}^{+}$in the phytoplankton $\mathrm{N}$ pool suggests that either very low phytoplankton growth rates resulted in an $\mathrm{N}$ turnover time that exceeded the travel time sampled during this study, or a portion of the phytoplankton community continued to access nitrate even in the presence of elevated $\mathrm{NH}_{4}{ }^{+}$concentrations.
\end{abstract}


